\title{
Optimization model: the innovation and future of e-ecotourism for sustainability
}

\author{
Fauziah Eddyono, Dudung Darusman, Ujang Sumarwan and Tutut Sunarminto
}

\begin{abstract}
Purpose - This study aims to find a dynamic model in an effort to optimize tourism performance in ecotourism destinations. The model structure is built based on competitive performance in geographic areas and the application of ecotourism elements that are integrated with big data innovation through artificial intelligence technology.

Design/methodology/approach - Data analysis is performed through dynamic system modeling. Simulations are carried out in three models: First, existing simulation models. Second, Scenario 1 is carried out by utilizing a causal loop through innovation of big data-based artificial intelligence technology to ecotourism elements. Third, Scenario 2 is carried out by utilizing a causal loop through big data-based artificial intelligence technology on aspects of ecotourism elements and destination competitiveness.

Findings - This study provides empirical insight into the competitiveness performance of destinations and the performance of implementing ecotourism elements if integrated with big data innovations that will be able to massively demonstrate the growth of sustainable tourism performance.
\end{abstract}

Research limitations/implications - This study does not use a primary database, but uses secondary data from official sources that can be accessed by the public.

Practical implications - The paper includes implications for the development of intelligent technology based on big data and also requires policy innovation.

Social implications - Sustainable tourism development.

Originality/value - This study finds the expansion of new theory competitiveness of ecotourism destinations. Keywords Dynamic model, Destination competitiveness, Ecotourism element

Paper type Research paper

\section{Introduction}

Competition and globalization is a challenge for ecotourism destinations in an effort to develop and introduce new products, services and concepts at high speed so as to provide space for new customer demands that require a sustainable innovation management response in the future. Future innovation management is about how an institution can ensure its innovation management function is ready to face future challenges (Jones et al., 2016). Future tourism innovation strategies include a big data approach in an effort to map the potential and strengthen various aspects of tourism. Big data consists of much larger datasets that can capture information on a much larger scale and potentially reflect longitudinal changes in real-time (Kitchin, 2013). Indeed, the rapid development of technology and big data analytics has transformed tourism research (DeLyser and Sui, 2013). Recent advances in big data technology and analytics have also brought innovative research approaches, unconventional data sources and vast amounts of information providing new opportunities for ecotourism research.

The digital transformation that occurred in the recent 4.0 revolution era has also been able to change the entire cycle of the tourism ecosystem, including being the cause of the shift in cyber and visual culture for tourists. The impact of the shift in cyber culture, which can be seen from digital transformation in the 4.0 revolution era, is a change in the decision-making process for traveling to
Fauziah Eddyono is based at the Doctoral Study Program of Ecotourism Management and Environmental Services, IPB University, Bogor, Indonesia.

Dudung Darusman is based at the Department of Forestry Management, IPB University, Bogor, Indonesia.

Ujang Sumarwan is based at the Department of Family and Consumer Science, IPB University, Bogor, Indonesia. Tutut Sunarminto is based at the Department of Forest Resources Conservation and Ecotourism, IPB University, Bogor, Indonesia.
Received 18 March 2021 Revised 14 September 2021 20 September 2021 Accepted 21 September 2021

(c) Fauziah Eddyono, Dudung Darusman, Ujang Sumarwan and Tutut Sunarminto. Published in Journal of Tourism Futures. Published by Emerald Publishing Limited. This article is published under the Creative Commons Attribution (CC BY 4.0) licence. Anyone may reproduce, distribute, translate and create derivative works of this article (for both commercial and non-

commercial purposes), subject to full attribution to the original publication and authors. The full terms of this licence may be seen at http://creativecommons.org/ licences/by/4.0/legalcode. 
ecotourism destinations (Eddyono, 2020). Thus, this change in travel decision-making forces the management of ecotourism destinations to adapt in managing the supply aspect of ecotourism in an effort to meet the needs of tourists. Management of ecotourism destinations must be able to find future innovations with the concept of "present" through a big data approach.

Eddyono (2020) illustrates that innovation in managing national parks as ecotourism destinations in the future requires three main pillars, namely big data, ecotourism elements and destination competitiveness. Big data is used to analyze the behavior of ecotourism tourists, predict trends and produce faster and more detailed statistics in an effort to improve supply performance of ecotourism destinations based on tourists' digital footprints. The ecotourism element is the application of ecotourism standards related to the protection of ecosystems and the maintenance of unique ecosystems where ecotourism attractions are located, which is a significant attraction for tourists (WTO, 2004). In addition to requiring the attractiveness of ecotourism elements, national park sites also require a facilitating element in the form of tourism competitiveness in the region so that ecotourism destinations are more easily accessible to tourists and to make it easier for tourists to meet their needs while traveling (Eddyono et al., 2021b).

National parks as ecotourism destinations are also the management of niche tourism destinations so that progressive data drive online reputation management also takes on a strategic role. Niche tourism refers to how particular tourism products can be adjusted to meet the needs of specific market segments; the more a manager knows about tourist perceptions, the more he can attract new tourists (Tussyadiah, 2014). In the digital era, as it is today, it is marked by the abundance of freely available information online (Petruzzelli et al., 2012), and the information in the form of big data set is now available to anyone who can analyze it. Besides, big data contains so much information that it can provide all the information needed by the park manager to monitor better than ever about the perceptions of tourists (Raguseo, 2018; Scuotto et al., 2017).

Although there is no complete definition of what big data is, it can be said that big data is a feature of having large data volumes, speed (data generated in real time), variety (structured and unstructured) and resolution (highly detailed) (Kitchin, 2014). The use of big data in research is not only able to examine causal relationships but is also able to describe the relationships between links (Zhang et al., 2018) and bring traditional research (micro-level) to a macro-scale (Wu et al., 2015). Big data sources include not only large administrative datasets (Connelly et al., 2016) but also data generated by sensors, cell phones and radio frequency identification (Heerschap et al., 2014). Big data is used for management performance improvement strategies because the use of big data is able to analyze consumer behavior, predict trends and produce faster and more detailed statistics so as to shift social science research into data driven, which is called the fourth research paradigm (Kitchin, 2013).

In developing a tourism destination that has a national park, two factors can be created, namely the performance of the destination competitiveness and the performance of the application of ecotourism elements in the national park (Eddyono, 2020). Gooroochurn and Sugiyarto (2005) argue the issue of competitiveness of tourism destinations is becoming increasingly important, especially for countries and regions that are highly dependent on tourism. A destination can be considered competitive if it can attract and satisfy potential tourists. The competitiveness of a destination directly influences tourism revenue in terms of the number of visitors and expenses, and the competitiveness of the destination will also indirectly affect businesses related to tourism, such as hotels and retail industries in tourism destination. Because of the enormous contribution of tourism to economic growth, the tourism industry and related issues have received much attention, especially on competitiveness. Many countries and regions recognize the importance of the economic development of tourism, which starts by utilizing various resources to improve the image and tourist attraction in the eyes of foreign tourists (Ritchie et al., 2000).

Related to the application of ecotourism elements in national parks, its performance refers to the perspective of ecotourism destination indicators that focus on ecotourism elements. Implementation performance refers to the view of sustainable tourism development indicators (WTO, 2004). It is in line with the theory of ecotourism, where ecotourism is tourism that is in 
harmony with the environment and social life, contributes positively to the local economy and conservation of protected areas and educates tourists about nature and local culture (Gössling and Hultman, 2006).

This study aims to find a dynamic model in an effort to increase performance of tourism as the number of foreign tourist arrivals and tourism receipts in ecotourism destinations is based on the competitiveness performance of destinations, and the performance of implementing ecotourism elements is integrated with big data. The modeling database leverages the competitive performance and application of ecotourism elements in national parks in Indonesia. The results of this analysis will provide a comprehensive picture of the increase in which the performance of destination competitiveness and the performance of the application of ecotourism elements and the use of big data innovations can increase the number of foreign tourist visits and tourism revenue in ecotourism destinations.

The results of this analysis will provide an overview of which performance is the competitiveness and performance that supports the ecotourism element, and the utilization of big data innovations can increase the number of foreign tourists to the national park as ecotourism destination. The effect of economic life caused by tourism comes from the visit of foreign tourists in a tourism destination; the visit of foreign tourists can provide prosperity and welfare for residents, where tourism is developed (Clement, 1961).

The selection of the modeling database is because national parks are one of the potential of ecotourism destinations in Indonesia. Until 2020, Indonesia has recorded 54 national park sites, spread across geographical districts and cities with an area of almost 16.3 million hectares (KLHK, 2017). National parks in Indonesia are nature conservation areas that have unique characteristics of biodiversity and ecosystems that function as protection of life support systems and are managed according to zoning systems. The national park, which is used for ecotourism activities, is in a utilization zone. The relatively undisturbed utilization area has unique natural values and high conservation interests that have the potential for ecotourism development to provide significant benefits for the surrounding area (Bismark and Sawitri, 2014). The choice of tourism destination areas is a central element in travel decisions (Damanik and Weber, 2006).

\section{Materials and methods}

\section{Data analysis method}

Data analysis is performed through dynamic system modeling. Dynamic systems are mathematical solving techniques by describing small problems that will be more easily solved (Hiller and Liberman, 1980). Dynamic system analysis is part of the system approach that comes from developing system theory. The system approach has two general characteristics, namely (1) in all the essential factors that exist find an excellent solution to solve the problem and (2) a quantitative model is made to form decisions rationally (Marimin, 2005). Further, Forrester (1994) states that dynamic systems are systems that have a passionate nature (change with time), and the structure of the phenomenon contains at least one feedback structure.

The probabilistic model is one of the dynamic system models that forms the basis of the model in this study. A probabilistic model is a statistical model that can be used when product demand or other factors are unknown but can be found using a probability distribution. Thus, probabilistic models are real-world adjustments because demand and waiting times are not always known and are constant (Dimyati and Dimyati, 1992).

\section{The operational stages of the model}

\section{Stock flow diagram}

Building a stock-flow map is a depiction of the interrelationships of existing structures in the form of stock (level), flow, auxiliary, constant and information link (Figure 1). The existence of stock and flow structures in real life must be represented in the model (Sterman, 2002). 


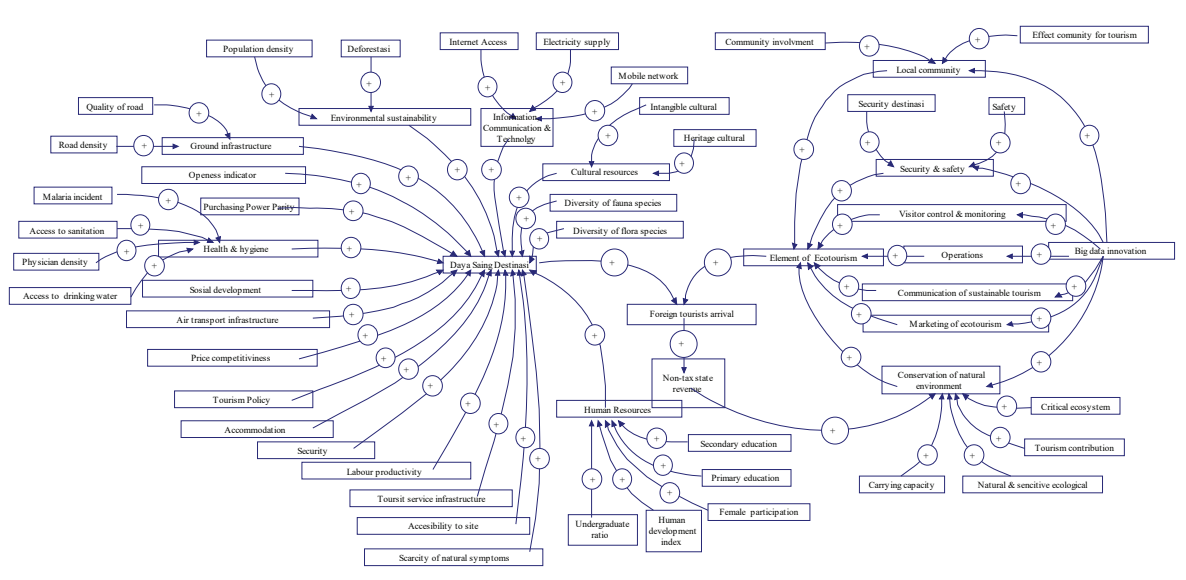

\section{Dynamic system model}

The active system model consists of two sub-models, namely the competitiveness performance model of destinations to the number of foreign tourist visits and the performance model of the application of ecotourism elements to the number of tourist visits. The most commonly used factor in measuring international tourism demand is tourist arrival from the country and area of origin to a particular destination, followed by tourist expenditure and staying in accommodation registered at the destination (Gao-jun and Xuan-tao, 2003; Song et al., 2008). Tourist arrivals usually function as dependent factors in tourism demand studies, and factors that influence tourist arrivals are often considered explanatory factors (Geiger and Goh, 2012). Other reviews also say almost the same thing; in the tourism demand literature, the dependent factor is the number of tourist arrivals (Mieczkowski and Chadee, 1987; Gunadhi and Boey, 1986; Patsouratis et al., 2005), per capita vacation visits (Martin and Witt, 1988)) or tourist expenses (González and Moral, 1995; Papatheodorou, 1999; Thompson and Thompson, 2010).

Several studies have shown that many factors can influence tourist arrivals, including transportation accessibility, weather, economic environment and duration of travel (Albalate and Bel, 2010; Cho, 2003; Taylor and Ortiz, 2009; Van der Merwe and Saayman, 2008; Eddyono et al., 2021a). As indicated by Cizmar and Weber (2000), the choice of a tourism destination remains one of the first and most important decisions made by tourists; and this decision is in turn mainly subject to many external factors, such as the country's image, accessibility, attractiveness, safety and others. Special attention to competitiveness must be directed at improving the way management of destinations that focuses on creativity, tourist safety, demand conditions, historical and cultural heritage resources, organizers and cleanliness (Pansiri, 2014).

Referring to the perspective of sustainable tourism development indicators, the application of sustainable practices in ecotourism destinations focus on the following elements: (1) conservation of the natural environment; (2) relations with local communities, preservation of cultural assets; (3) operation of national parks; (4) references with local communities and conservation of cultural assets; (5) operationalization of National Parks; (6) ecotourism marketing and (7) tourist security and safety (WTO, 2004). The application of ecotourism elements is the pillars of the sustainability of ecotourism destinations such as elements of nature conservation, local community relations and preservation of cultural assets, operationalization as well as the security and safety of ecotourism activities (Eddyono, 2020).

The purpose of nature conservation is to conserve resources, especially biodiversity, and maintain sustainable use of resources, which bring ecological experience to travelers, preserve the 
ecological environment and get economic benefits (Fajnylber, 1988). Ecotourism standards related to ecosystem protection, including the maintenance of ecosystems where ecotourism attractions are located, protection and care of wildlife, especially endangered species, and wildlife living in harmony with humans, rare flora and fauna and unique ecosystems are significant attractions for tourists (OECD, 1992). Biodiversity is a substantial asset for nature-based tourism, which has experienced rapid growth. There are mutual benefits between sustainably managed tourism and nature conservation where tourism has significant potential to contribute to biodiversity conservation because biodiversity is an essential component of the natural environment enjoyed by tourists (WTO, 2004).

An essential part of ecotourism activities is experiencing the lifestyles of traditional communities that inhabit natural areas. The small community, traditional, authenticity is very sensitive to the sociocultural impact of tourism. Active participation and agreement of local communities in sustainable ecotourism management are fundamental. Community participation in the definition of indicators and monitoring processes is crucial because tourism will affect their daily lives, and they are the people who can best evaluate the impact and decide the level of ecotourism activities that meet the expectations of the local community. Ecotourism requires a combination of conservation and tourism (the economics associated with it) to benefit local communities, especially those that focus on environmental sustainability (Van der Merwe and Saayman, 2008).

The operationalization of ecotourism is usually expected to minimize negative impacts on the natural environment and socio-culture and contribute to the conservation of natural areas. For this reason, ecotourism activities are typically organized by specialist tour operators for small groups. The level of sustainability of an ecotourism destination depends on operational practices and the quality of services offered. Indicators can help measure the achievement of operational standards for destination managers as in the certification system and can help in achieving control of tourism impacts (WTO, 2004). Operationalization is also related to carrying capacity. The tourism carrying capacity is defined as the maximum number of people who can visit tourism destinations at the same time, without causing environmental, sociocultural, economic damage and an unacceptable decline in the quality of visitor satisfaction (Mowforth and Munt, 2015).

The application of ecotourism elements gives a special place to the marketing concept. The importance of proper marketing is widely recognized throughout the tourism sector, which today, the tourism market has been increasingly segmented through communication methods to reach consumers has multiplied and varied (Boghean and Boghean, 2006).

Ecotourism activities are often held in remote areas with certain conditions, for example in rain forests, deserts and mountains that involve physical activities, such as tracking, canoeing and others. According to a study of the factors that are at the center of sustainable ecotourism (Bassotti, 2003), the safety of activities is the second most important for tourists, after environmental protection. Indicators that respond to the safety and security of destinations and their operations are fundamentally consisting of public security and tourist security.

\section{Causal loops}

Make a causal loop diagram which is a picture of the reciprocal relationship or cause and causal effect (causal relationship) of existing structures (Figure 1). System dynamics describes the system elements that interact with each other in feedback (causal loop) and subsequently will produce specific behaviors. Causal loops are developed in a diagram of the feedback process. Diagrams can be used in a variety of situations and conditions because the causal loop can present the relationship between the elements forming and the feedback process (Sterman, 2000).

\section{Simulation model}

Simulation is a method used to study the dynamics of a phenomenon. The phenomenon is known to be structured, for example in the form of a collection of units, parts or elements that operate in 
several interconnected ways. Simulation describes the behavior of phenomena (systems) in their development over time. The simulation results show that the action of the network has grown, for example, the first time it rises like the $S$ (sigmoid) curve, where the increase is prolonged at first. Growth is exponential for a period and is ended by saturation (Sterman, 2002).

This model simulation utilizes secondary data from government and nongovernment parties through library research methods (Zed, 2004). Secondary data sources are official public data that are already available in government agencies and nongovernment institutions. The method of collecting destination competitiveness data refers to the Travel and Tourism Competitiveness Index, Competitiveness Monitor and Indicator Measuring Competitiveness in Tourism (IMCT).

This study conducts simulations of each regional cluster. Indonesia has three regional clusters, namely the outer Java and Bali cluster, the Java cluster region and the Bali cluster region. Simulations are carried out in three models, namely simulation of the existing model, which is the simulation of existing data from 2014 to 2018. The second simulation (Scenario 1) is carried out by leveraging causal loops through the innovation of artificial intelligence technology based on big data to ecotourism elements. The third simulation (Scenario 2) was carried out by leveraging causal loops through artificial intelligence technology based on big data to the aspects of ecotourism and destination competitiveness (Figure 2).

\section{Structural validation}

Structural validation is a white-box validation, where a cross-check of the model has been produced and reviewed by experts in related fields (Sushil, 1993), in this case for the area of destination competitiveness and ecotourism elements. In structural validation, validity testing is carried out on the extent of similarity of the structure of the model with the format in reality, which is shown by the extent to which the interaction of the model factors resembles the exchange of real events. Verification of structures involved in the process of the model being built (Table 1) and described as a micro conception (Figure 1).

\section{Output/performance validation}

Validating output/performance, which is to obtain the confidence to what extent the performance of the models from each cluster is following actual-world performance so that it qualifies as a factabiding scientific model. The simulation model that is built must be representative and logical so that it can describe the real world; this is done through the validation of the recommended statistical methods (Tasrif, 2006). Among the several methods commonly used for validation

Figure 2 Simulation model of the performance of destination competitiveness, performance of implementing ecotourism elements and data on foreign tourist visits

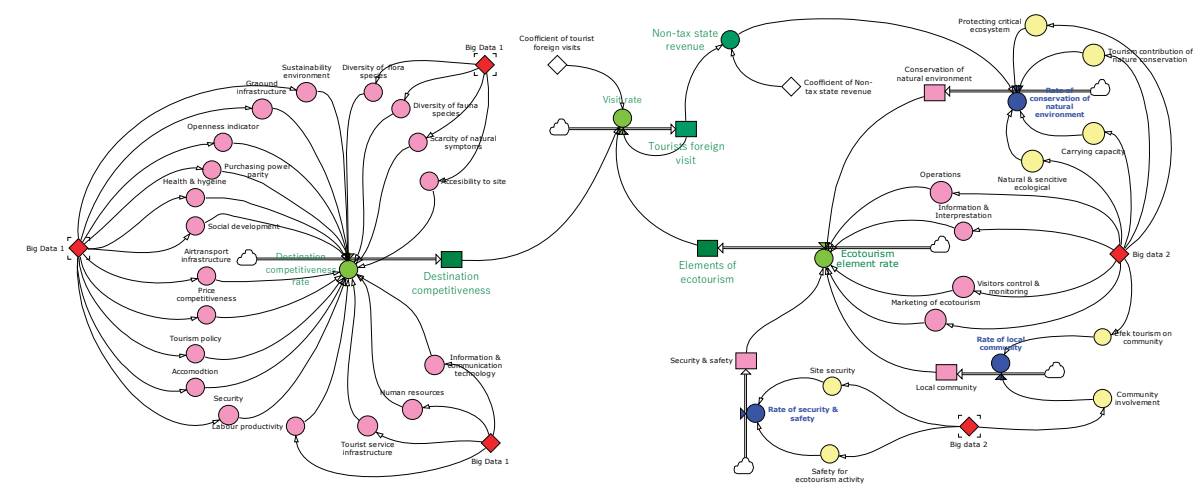

PAGE 6 JOURNAL OF TOURISM FUTURES $\mid$ VOL. $\mathbf{m}$ NO. $\mathbf{m}$ 
Table 1 Model structure validation of elements of ecotourism and destination competitiveness

The element of ecotourism toward tourist visits

(2) The contribution of tourism to nature conservation

(3) Nature and sensitive ecology

(4) Carrying capacity

(5) Community involvement

(6) Community effects on tourism

(7) National park operations

(8) Visit control

(9) Ecotourism marketing

Goodwin (1996), Mowforth and Munt (2015), WTO (2004), Leiper (1979)

(10) Tourist safety

Tourist visits toward conservation

WTO (2004), Leiper (1979)

WTO (2004), Leiper (1979), Manning (2013)

WTO (2004), Roberts et al. (2005), The International Ecotourism Society (2000)

WTO (2004), Roberts et al. (2005)

WTO (2004), Dodds and Jolliffe (2016)

WTO (2004), Mowforth and Munt (2015), Manning (2013)

WTO (2004), Diamantis (2004), Lovelock and Patterson (2015), Sangpikul (2008), Bassotti (2003), Boghean and Boghean (2006)

WTO (2004), Cizmar and Weber (2000), Bassotti (2003)

WTO (2004), Fennell (1999, 2013), Catibog-Sinha (2008), de Boer et al. (2007)

Destination competitiveness towards tourist visits

(1) Territorial security Cizmar and Weber (2000)

(2) Health and sanitation

Cizmar and Weber (2000)

(3) Lodging accommodation

(4) Manpower productivity

(5) Human resources

(6) Purchasing power value

(7) Hotel index price

(8) Information technology and communication

(9) Tourist policy

(10) Air transportation infrastructure

(11) Land transportation infrastructure

(12) Tourism service infrastructure

(13) Openness in accepting foreign tourists

(14) Environmental sustainability

(15) Human resources

(16) Diversity of flora species

(17) Diversity of fauna species

(18) Scarcity of natural phenomena

(19) Accessibility to the site

Big data on the performance

Ritchie et al. (2000), UNWTO (2017), Wahab (1977)

UNWTO (2017), Ritchie et al. (2000)

UNWTO (2015, 2017), Ritchie et al. (2000)

Ritchie et al. (2000)

Yoeti (2008)

Yoeti (2008), Sukirno (2004)

UNWTO (2017), Ritchie et al. (2000)

Cizmar and Weber (2000), Ritchie et al. (2000), Yoeti (2008), Wahab (1977)

Cizmar and Weber (2000), Yoeti (2008)

Ritchie et al. (2000), Yoeti (2008), Wahab (1977)

UNWTO (2017), Ritchie et al. (2000)

UNWTO (2017), Ritchie et al. (2000)

UNWTO (2017), Ritchie et al. (2000), Yoeti (2008), Wahab (1977)

WTO (2004)

WTO (2004)

WTO (2004)

WTO (2004), Yoeti (2008)

Narendra (2015), Fuchs et al. (2014), Aarikka-Stenroos and Jaakkola (2012), Gretzel et al. (2015) Jackson (2016), Buhalis and Amaranggana (2015), Vargo and Akaka (2009)

purposes are the Theil statistical test and one error measurement method used in this study is RMSPE (root mean square per cent error) or the percentage error of the mean square root. The model is declared valid, so the error must be small and sourced from nonsystematic errors (Sterman, 2002). MAPE (mean absolute percentage error) or the average percentage of absolute error or also known as the average percentage of deviation is a measure of the accuracy of prediction of forecasting methods in statistics (Yamin and Shahidehpour, 2004).

\section{Results and discussion}

\section{Regional cluster modeling}

Modeling simulations are carried out to get a picture of changes in the time scale. The results of the analysis of competitiveness destination and ecotourism element performance data were obtained in five years, which are then carried out as simulations with a dynamic system to get a picture of changes in the number of tourist visits and tourism revenue reception in that period. The dynamic simulation conducted is a simulation of an existing model (2014-2018). Graphic simulation results of the current models in a region cluster outside of Java and Bali, Java region cluster and Bali region cluster (Figures 3-5). 
Figure 3 Graphic simulation of the competitiveness of destination and ecotourism element in the existing model of the region outside of Java and Bali cluster

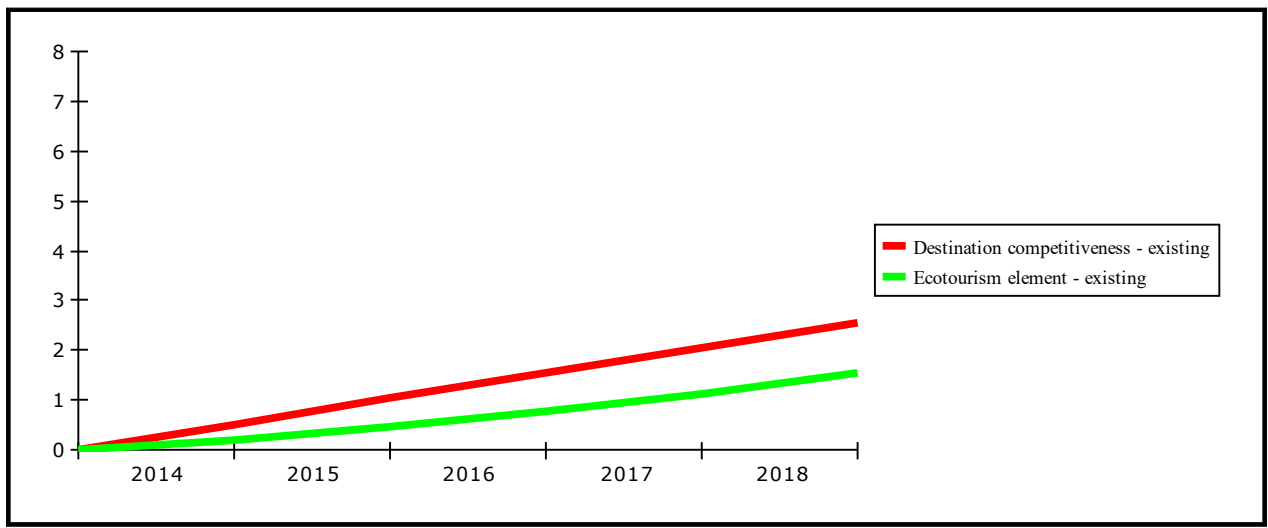

Figure 4 Graphic simulation of the competitiveness of destination and ecotourism element in the existing model of the region Java cluster

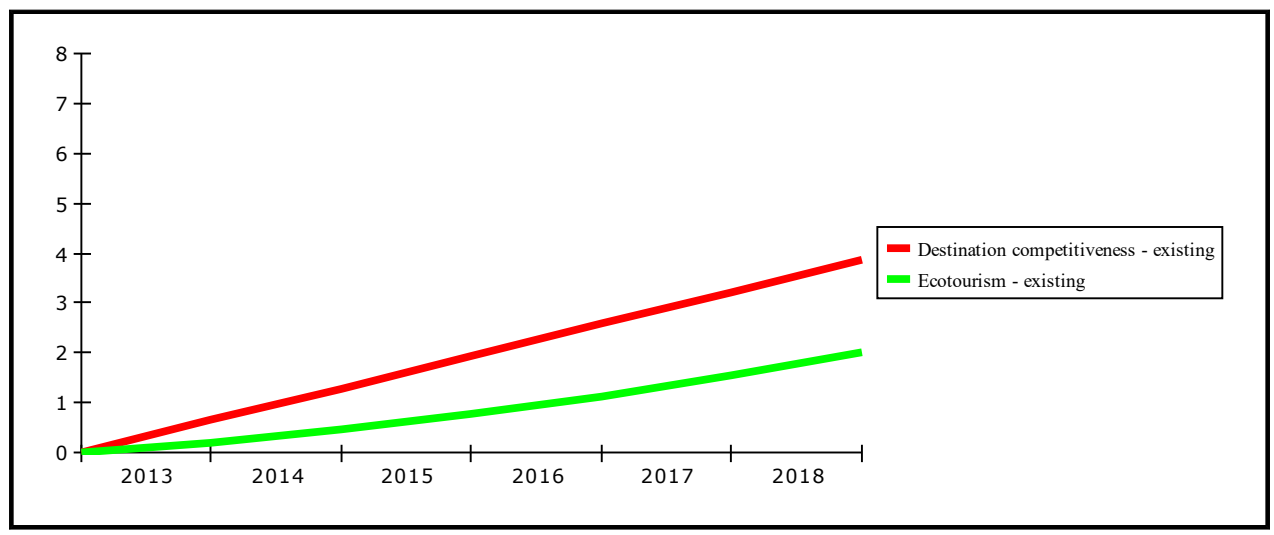

Figure 5 Graphic simulation of the competitiveness of destination and ecotourism element in the existing model of the region Bali cluster

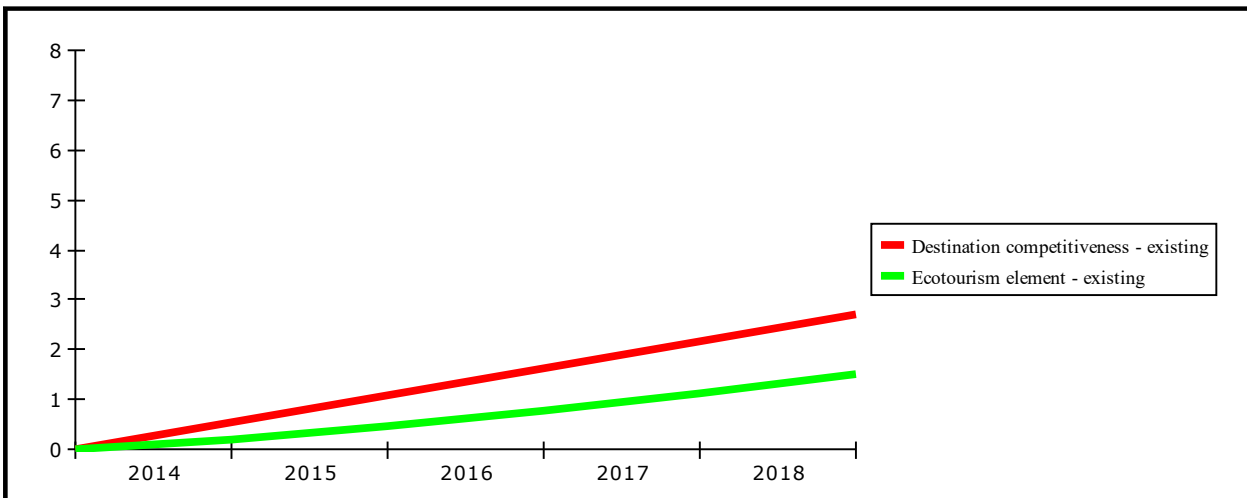

PAGE 8 JOURNAL OF TOURISM FUTURES $\mid$ VOL. $\mathbf{m} \mathbf{m}$ NO. $\mathbf{m}$ 
The results of simulation models of existing cluster region outside Java and Bali, Java region cluster and Bali region cluster found that the value of destination competitiveness and the application of ecotourism elements experienced linear growth over time, where within a period of five years (2014-2018), it appears that the power performance destination competitiveness and the application of ecotourism elements consistently increase.

\section{Test validity of performance}

Validation of output/performance used data on tourist visits over a period of five years in clusters outside Java and Bali (Figure 6), clusters in Java (Figure 7) and clusters in Bali (Figure 8). Graphically, it appears that the three models are quite good in describing the real world (Sterman, 2002).

In addition to the Theil statistical test, a simple statistical test using MAPE was also used to see the accuracy and level of validity of the model. Based on the validation results (Table 2), the MAPE value in the outer Java and Bali cluster is $6.20 \%$, the Java region cluster is $4.95 \%$ and the Bali region cluster is $15.72 \%$. The values for the clusters of regions outside Java and Bali and clusters in the Java region show the MAPE value $(\leq 10 \%)$, which means that the accuracy of the model is high. The Bali area cluster showed MAPE values (10\% < MAPE 20\%), classified as good accuracy. Thus, the three simulation models developed are considered reliable and good enough to be used as simulation models and have high prediction accuracy (Chang et al., 2017).

\section{Figure 6 The accuracy of the cluster model for region outside Java and Bali}

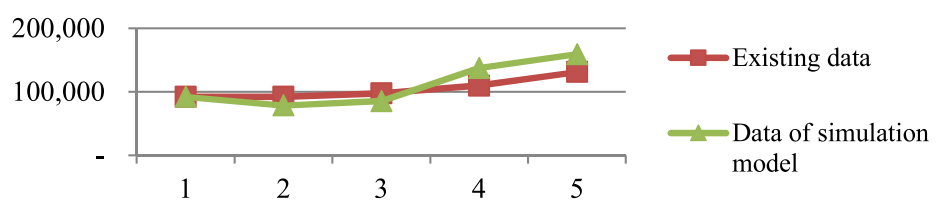

Figure 7 The accuracy of the cluster model for region Java

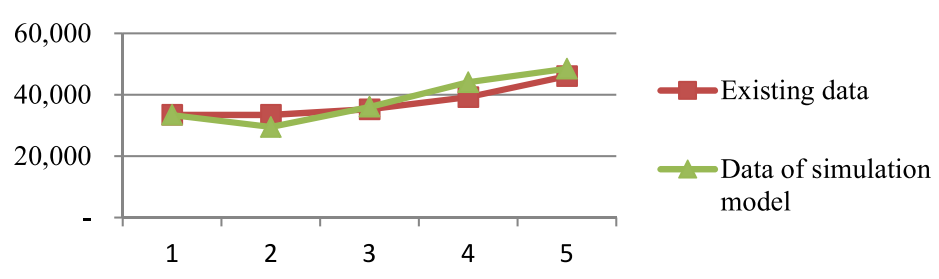

Figure 8 The accuracy of the cluster model for region Bali

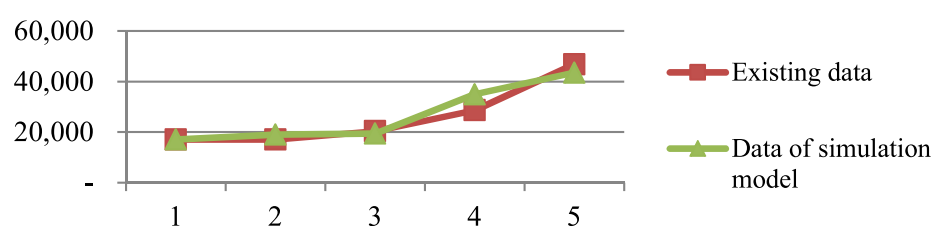

\begin{tabular}{l|l|l} 
VOL. $m$ NO. $m$ & JOURNAL OF TOURISM FUTURES & PAGE 9
\end{tabular} 
Table 2 Validation of tourist visit performance for all clusters

\begin{tabular}{|c|c|c|c|c|}
\hline Year & Existing tourist visit & Model tourist visit & Diff MAE & MAPE \\
\hline \multicolumn{5}{|c|}{ Region outside Java and Bali cluster } \\
\hline 2014 & 92.228 & 92.228 & - & - \\
\hline 2015 & 78.785 & 92.228 & $(13,443)$ & $(0.17)$ \\
\hline 2016 & 85.578 & 97.809 & $(12,231)$ & $(0.14)$ \\
\hline 2017 & 137.800 & 110.092 & 27,708 & 0.20 \\
\hline \multirow[t]{2}{*}{2018} & 159.381 & 131.580 & 27,801 & 0.17 \\
\hline & & & 29,835 & $6.20 \%$ \\
\hline \multicolumn{5}{|c|}{ Region Java cluster } \\
\hline 2014 & 33.459 & 33.459 & - & - \\
\hline 2015 & 29.534 & 33.459 & $(3,925)$ & (0.13) \\
\hline 2016 & 36.128 & 35.292 & 836 & 0.02 \\
\hline 2017 & 44.153 & 39.286 & 4,867 & 0.11 \\
\hline \multirow[t]{2}{*}{2018} & 48.546 & 46.164 & 2,382 & 0.05 \\
\hline & & & 4.160 & $4.95 \%$ \\
\hline \multicolumn{5}{|c|}{ Region Bali cluster } \\
\hline 2014 & 17.063 & 17.063 & - & - \\
\hline 2015 & 19.059 & 17.063 & 1.996 & 0.10 \\
\hline 2016 & 19.482 & 20.427 & $(945)$ & $(0.05)$ \\
\hline 2017 & 35.009 & 28.765 & 0.244 & 0.18 \\
\hline \multirow[t]{2}{*}{2018} & 43.602 & 46.976 & (3.374) & $(0.08)$ \\
\hline & & & 3.921 & $15.72 \%$ \\
\hline
\end{tabular}

\section{Simulation model of artificial intelligence technology innovation based on big data}

The simulation model is a model that is carried out for changes based on the determinant attributes. Scenario model 1 is done by using the controlling factor of the model, namely the innovation factor of artificial intelligence technology based on big data by utilizing the performance of the application of ecotourism elements to increase the number of tourist visits on a massive scale so that it has an impact on the acceptance of revenue tourism without intervening to optimize the application of the ecotourism element. While the Scenario model 2 utilizes the controlling factor of an artificial intelligence innovation model based on big data by using the performance of ecotourism elements that are integrated with the performance attributes of destination competitiveness in the geographical area of the national park. Changes in tourist growth in the existing model, Scenario model 1 and Scenario model 2 are presented in Table 3, Figures 9-11.

Based on the results of model simulations (existing model, Scenario model 1 and Scenario model 2) showed significant differences. Of the three scenarios, Scenario model 2 shows a very massive growth in tourism performance. In cluster areas outside Java and Bali, the growth in the number of tourist visits before the simulation was carried out was on average in the range of $13 \%$ per year. With the simulation of Model 1 (Figure 9), there is a growth in the number of tourists and tourism income of $18 \%$ per year, respectively. With the simulation of Model 2 , there is a growth in visits of $26 \%$ per year which the was only around $13 \%$ in the previous the existing model.

The simulation results in the Java region cluster show that at the beginning of simulation time (2014), all three models experienced the same conditions, namely the intersection or meeting point between the growth of tourist visits in the existing model, Scenario model 1 and Scenario model 2 (Figure 10). The acceleration was due to an intervention on the innovation factor of artificial intelligence technology based on big data on the application of ecotourism elements. In connection with this intervention, the estimated number of tourists to the national park has increased by an average of $11 \%$ per year during the period 2014-2018. However, if intelligence technology innovation interventions are based on big data, it is carried out on ecotourism marketing through the use of factors in the application of ecotourism elements and competitiveness performance destination, and the growth in the number of tourists and tourism revenue will increase and be more massive, on average $21 \%$ during the period $2014-2018$.

PAGE $10 \mid$ JOURNAL OF TOURISM FUTURES $\mid$ VOL. 
Table 3 Model simulation and tourism performance

\begin{tabular}{|c|c|c|c|c|c|c|}
\hline \multirow[b]{2}{*}{$\begin{array}{l}\text { Model } \\
\text { simulation }\end{array}$} & \multicolumn{3}{|c|}{ Foreign tourist visit growth } & \multicolumn{3}{|c|}{ Tourism revenue growth } \\
\hline & $\begin{array}{c}\text { Cluster of } \\
\text { outside Java } \\
\text { and Bali region }\end{array}$ & $\begin{array}{l}\text { Cluster of } \\
\text { Java } \\
\text { region }\end{array}$ & $\begin{array}{l}\text { Cluster of } \\
\text { Bali region }\end{array}$ & $\begin{array}{c}\text { Cluster of } \\
\text { outside Java } \\
\text { and Bali region }\end{array}$ & $\begin{array}{c}\text { Cluster of } \\
\text { Java } \\
\text { region }\end{array}$ & $\begin{array}{l}\text { Cluster of } \\
\text { Bali region }\end{array}$ \\
\hline $\begin{array}{l}\text { Existing } \\
\text { model }\end{array}$ & $13 \%$ & $11 \%$ & $41 \%$ & $6 \%$ & $9 \%$ & $13 \%$ \\
\hline $\begin{array}{l}\text { Scenario } \\
\text { model } 1\end{array}$ & $18 \%$ & $13 \%$ & $80 \%$ & $13 \%$ & $8 \%$ & $26 \%$ \\
\hline $\begin{array}{l}\text { Scenario } \\
\text { model } 2\end{array}$ & $26 \%$ & $21 \%$ & $124 \%$ & $20 \%$ & $28 \%$ & $40 \%$ \\
\hline
\end{tabular}

Note(s): Existing model: The existing model is built based on the performance factors of the application of ecotourism elements and the competitiveness of the destination. Scenario model 1: The model is built based on model control factors (big data-based artificial intelligence technology), which is integrated with the performance of implementing ecotourism elements. Scenario model 2: The model is built based on the model control factor (big data-based artificial intelligence technology), which is integrated with the performance of the application of ecotourism elements and attributes of destination competitiveness

\section{Figure 9 The simulations graphic of changes in the number of foreign tourist visits in the cluster area outside Java and Bali}

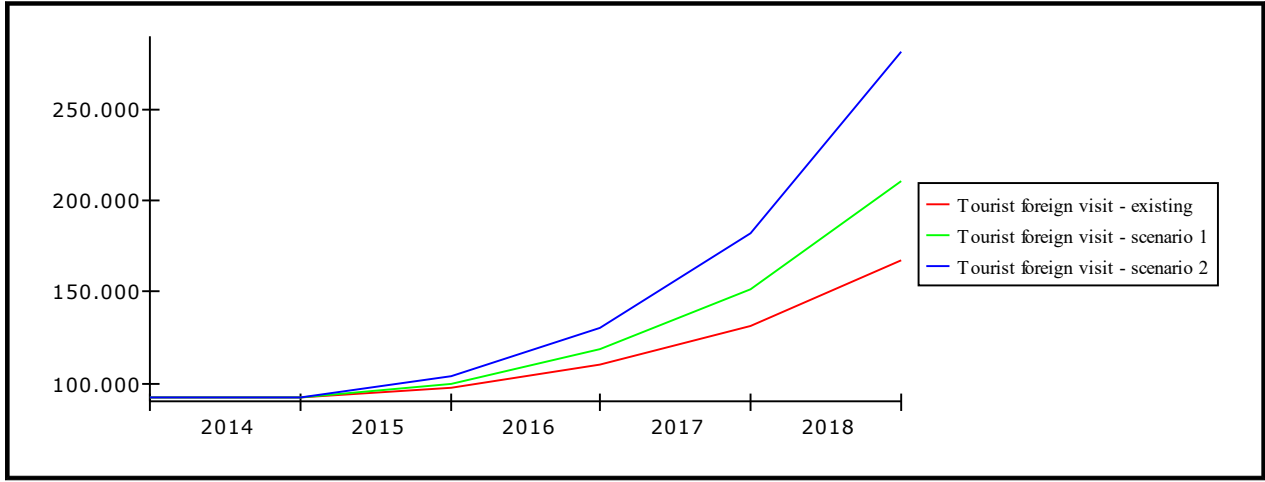

\section{Figure 10 The simulation graphic of changes in the number of tourist visits in the model} simulation in the Java region cluster

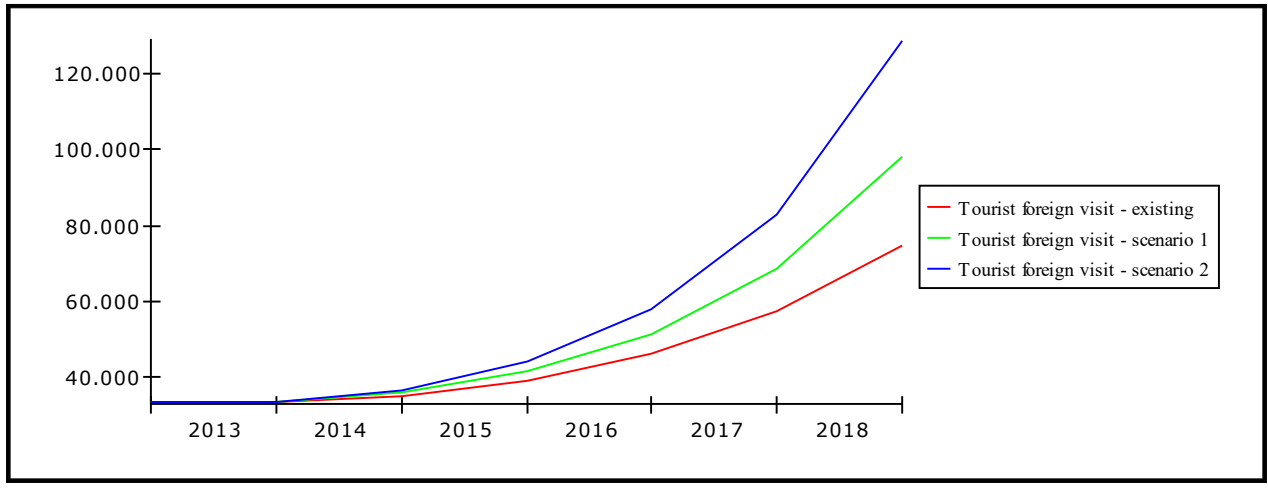

Simulation model 1 conducted in the Bali cluster region experienced a growth in the number of tourist visits before the simulation, an average of around $41 \%$ per year. With the scenario of model 1 , there is a growth in the number of tourists and tourism revenue each by $80 \%$ per year (Figure 11).

VOL. m. NO. m| $\mid$ JOURNAL OF TOURISM FUTURES $\mid$ PAGE 11 


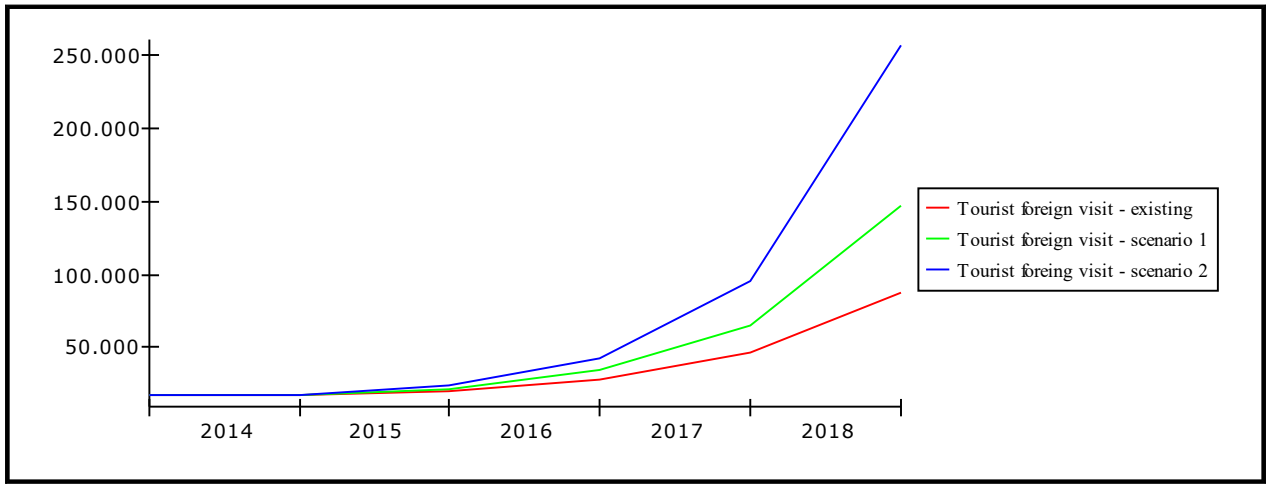

Very different things happen in the existing model, where tourist visits tend not to be so massive until 2018. While simulation model 2 utilizes the controlling factor of an artificial intelligence innovation model based on big data on the application of ecotourism elements. With the scenario of model 2 in the region cluster, there is a growth of visits of $124 \%$ per year. The increase is the result of a simulation of management change through artificial intelligence technology innovation based on big data (see Figures 12 and 13).

On the other hand, in fact, to travel to the utilization zone of the ecotourism destination like national park and explore the conservation area is not always easy. Most of these areas are not easily accessible because natural areas tend to be in remote areas (KLHK, 2017). The locations of ecotourism sites are generally located in remote areas, so there are often many obstacles to getting to the destination. The distance from the provincial capital which is far and limited transportation tends to hinder the acceleration of ecotourism development. Ecotourism destinations require a facilitating element in the form of tourism competitiveness in their region to make it more accessible to tourists, especially from foreign countries, and to make it easier for tourists to meet their needs during their traveling. This condition then causes the need for tourism competitiveness. The performance of tourism competitiveness in the geographical area of high ecotourism destinations will provide a better indication of tourist visits. Based on this, it can be understood that better

\section{Figure 12 Comparative graphic of changes in growth of foreign tourists visit in the all cluster area}

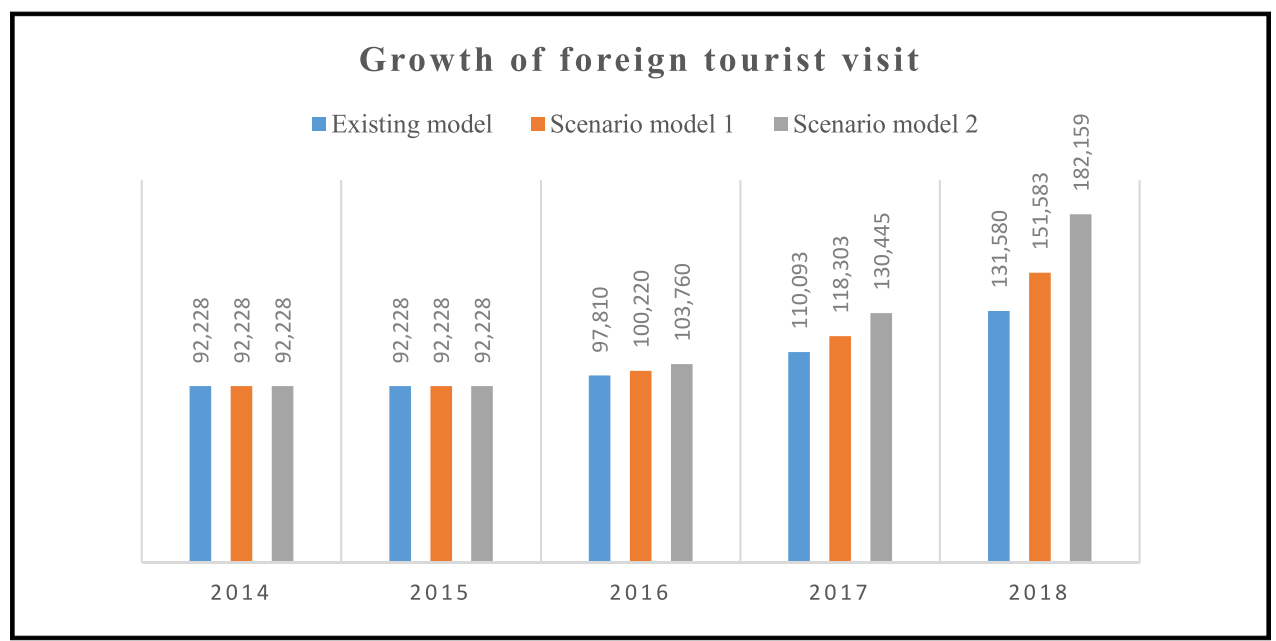

PAGE 12 |JOURNAL OF TOURISM FUTURES | VOL. m. NO. $\mathbf{m}$ 
Figure 13 Comparative graphic of changes in growth of revenue tourism in the all cluster area

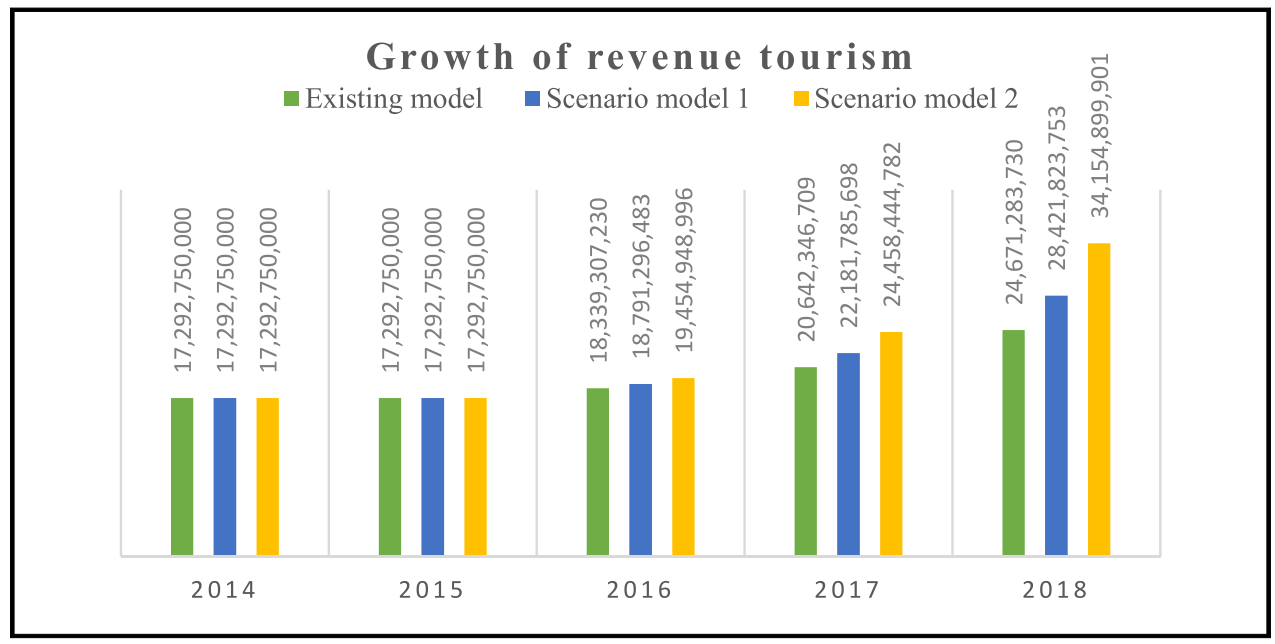

competitiveness will provide space for an increase in the number of tourist visits to potential tourism objects in an area (Eddyono et al., 2021a).

There are trade-offs between sustainably managed tourism and nature conservation. Such tourism has significant potential to contribute to the conservation of biodiversity, which is an important component of the natural environment enjoyed by tourists (WTO, 2004). This dualcomponent (ecological value and tourist value) is a challenge to ensure tourism development without destroying sensitive ecosystems. Ecotourism can provide the expected benefits for conservation and community development, so it should be an economically viable activity through tourist visits. National park tourist visits will be able to provide incentives for financing the conservation of the site and the economic benefits of local communities (Eddyono et al., 2021b). Thus, to develop ecotourism destinations, policy innovations are needed to integrate the competitiveness of destination, the application of ecotourism elements and the application of artificial intelligent big data applications called e-ecotourism innovation.

In responding to this tourism market opportunity, national park management also requires the adoption of artificial intelligence technology based on big data. In the era of openness of the industrial revolution 4.0 as it is today, an innovative approach based on artificial intelligence technology is inevitable (Schwab, 2016). Therefore, we need an innovation management process based on technology. The form of the development of destination artificial intelligence systems based on big data is integrated with the performance of the application of ecotourism elements in national parks and the management of destination competitiveness in the geographical area of National Parks in Indonesia. Along with the development of the 4.0 industrial revolution, digitization is increasingly becoming a requirement to be competitive in the tourism industry. For countries that do not integrate technology and increase connectivity will be left behind. In recent years, all states have significantly improved telecommunications infrastructure (The World Economic Forum, 2018). This revolution gave rise to various digital innovations through the use of databases by utilizing the Internet network and predicted by artificial intelligence so that it could turn productdriven into solution-driven, impersonal to personalized, reactive to predictive and human to human and machine (Schwab, 2016).

All developments and changes from this revolution led to the same key, namely through the use of the power of digitalization of information. Departing from this, like it or not, like it or not, national park management must start the process of innovation based on artificial intelligence technology based on data. The urgency of innovation-based management, because innovation is crucial in efforts to 
improve competitiveness, especially for long-term growth due to globalization, has made factors of production accessible everywhere (Forsyth and Farran, 2013).

This urgency must be supported by policy innovation as legal protection for stakeholders. In principle, a policy must cover three things, namely legal certainty, expediency and justice. Innovation-based management will be more effective in its application if it obtains fair legal certainty so that its usefulness can be obtained. The higher the norm settings, the stronger and more binding the implementation will be - mainly if the norm provides sanctions.

A learning from Japan: Japan is one of the countries that is quite serious about implementing ecotourism elements through legislation. Similar to Indonesia, national parks in Japan are also managed under the coordination of the Ministry of Environment. The ministry is responsible for promoting ecotourism in Japan and establishing an ecotourism promotion policy in 2008 based on a holistic development framework. The Ministry is actively promoting ecotourism with alternative uses of national parks (Hiwasaki, 2006). The national park used as a site model is the Iriomote Ishigaki National Park area and currently has developed into 13 ecotourism model projects (Yamada, 2011).

Another case with the management of ecotourism is in Nepal. In Nepal, there is no government policy specifically addressing ecotourism, except for homestay regulations. Ecotourism practices in Nepal are formed by three elements of general tourism policies, namely (1) tourism policies issued by the Nepalese government, such as tourism policies and initiatives were taken to celebrate the 2011 Nepal tourism year and the 2020 Tourism Vision; (2) Government institutions, such as the ministry of tourism and transportation and the national trust for nature conservation and (3) nongovernmental organizations, such as the world wild life fund for nature, the international union for nature and natural resource conservation, sustainable tourism networks and a global center for integrated.

\section{Conclusions}

The existing model shows that the performance of the application of ecotourism elements and the potential competitiveness of destinations in the national park's geographic region influence the visit of national park foreign tourists and have an impact on the growth of tourism revenue. To optimize the number of tourist visits that have an impact on the sustainable growth of tourism revenue, the model informs that artificial intelligence technology based on big data can be used as a leverage for the development of the number of foreign tourist arrivals and tourism revenue, if integrated with the existing performance conditions of the application of ecotourism elements and potential competitiveness in the geographical area cluster. Thus, it can be said that the competitiveness of ecotourism consists of two factors, namely the performance of destination competitiveness and the application of ecotourism elements. Ecotourism competitiveness can be optimized again if it is integrated with traces of ecotourism tourist behavior by utilizing big data-based artificial intelligent innovations. Knowledge of tourist tracks is used for the development of tourism destinations so that there is an optimization of competitiveness factors in a sustainable manner.

Innovation is a key driver of economic growth and social development (Marchese, 2009; Lewis, 2008; Adams et al., 2006). Research to understand the complex nature and management of innovation processes is essential for tourism stakeholder (academician, business, community and government). The application of intelligent technology based on big data also requires policy innovation. Policies that prioritize expediency, legal certainty and justice will be more quickly absorbed and practiced on a massive scale. As much as possible, the policy is at its highest rank because of its cross-sectoral and institutional arrangements. This can be carried out if the region building an institution destination management organization (DMO). Destination management and other stakeholders can formulate policy innovations in an effort to optimize the potential competitiveness factors of destinations in their respective region. This implementation can be implemented through the DMO approach. DMO is a tourism governance forum in areas whose

PAGE 14 JOURNAL OF TOURISM FUTURES $\mid$ VOL. ... NO. ... 
economic activity is dominated by the tourism sector as well as tourism activities in ecotourism destination.

\section{References}

Aarikka-Stenroos, L. and Jaakkola, E. (2012), "Value co-creation in knowledge intensive business services: a dyadic perspective on the joint problem solving process", Industrial Marketing Management, Vol. 41 No. 1, pp. 15-26.

Adams, R., Bessant, J. and Phelps, R. (2006), "Innovation management measurement: a review", International Journal of Management Reviews, Vol. 8 No. 1, pp. 21-47.

Albalate, D. and Bel, G. (2010), "Tourism and urban public transport: holding demand pressure under supply constraints”, Tourism Management, Vol. 31 No. 3, pp. 425-433, doi: 10.1016/j.tourman.2009.04.011.

Bassotti, G. (2003), “Factores de calidad en ecoturismo: una visión práctica para su aplicación”, Estudios Y Perspectivas En Turismo, Vol. 12 No. 1, pp. 7-23.

Bismark, M. and Sawitri, R. (2014), Nilai Penting Taman Nasional, Forda Press.

Boghean, C. and Boghean, F. (2006), "Ecotourism - a profitable and sustainable model for tourism resources", Revista de Turism, No. 1, pp. 43-47, available at: https://www.cabdirect.org/cabdirect/abstract/20093248327.

Buhalis, D. and Amaranggana, A. (2015), "Smart tourism destinations enhancing tourism experience through personalisation of services", Information and Communication Technologies in Tourism 2015, Springer, pp. 377-389.

Catibog-Sinha, C. (2008), "Zoo tourism: biodiversity conservation through tourism", Journal of Ecotourism, Vol. 7 Nos 2-3, pp. 160-178.

Chang, C.-W., Ushio, M. and Hsieh, C. (2017), "Empirical dynamic modeling for beginners", Ecological Research, Vol. 32 No. 6, pp. 785-796.

Cho, V. (2003), "A comparison of three different approaches to tourist arrival forecasting", Tourism Management, Vol. 24 No. 3, pp. 323-330, doi: 10.1016/S0261-5177(02)00068-7.

Cizmar, S. and Weber, S. (2000), "Marketing effectiveness of the hotel industry in Croatia", International Journal of Hospitality Management, Vol. 19 No. 3, pp. 227-240, doi: 10.1016/s0278-4319(00)00020-7.

Clement, H.G. (1961), The Future of Tourism in the Pacific and Far East: A Report Prepared by Checchi and Company under Contract with the United States Department of Commerce and Co-sponsored by the Pacific Area Travel Association, US Department of Commerce.

Connelly, R., Playford, C.J., Gayle, V. and Dibben, C. (2016), "The role of administrative data in the big data revolution in social science research”, Social Science Research, Vol. 59, pp. 1-12.

Damanik, J. and Weber, H.F. (2006), "Perencanaan Ekowisata Dari Teori ke Aplikasi”, Andi Offset.

De Boer, W.F., Stigter, J.D. and Ntumi, C.P. (2007), "Optimising investments from elephant tourist revenues in the Maputo Elephant Reserve, Mozambique", Journal for Nature Conservation, Vol. 15 No. 4, pp. 225-236.

DeLyser, D. and Sui, D. (2013), "Crossing the qualitative-quantitative divide II: inventive approaches to big data, mobile methods, and rhythmanalysis”, Progress in Human Geography, Vol. 37 No. 2, pp. 293-305.

Diamantis, D. (2004), Ecotourism: Management and Assessment, Cengage Learning EMEA.

Dimyati, T.T. and Dimyati, A. (1992), Operations Research Model-Model Pengambilan Keputusan, Sinar Baru Algensindo.

Dodds, R. and Jolliffe, L. (2016), "Experiential tourism: Creating and marketing tourism attraction experiences", The Handbook of Managing and Marketing Tourism Experiences, pp. 113-129.

Eddyono, F. (2020), Model optimasi penerapan elemen ekowisata dan daya saing destinasi berbasis inovasi mahadata pada taman nasional di Indonesia, IPB University.

Eddyono, F., Darusman, D., Sumarwan, U. and Sunarminto, T. (2021a), "Performance of tourism competitiveness in national park area of Indonesia", Journal of Environmental Management and Tourism, Vol. 12 No. 4, pp. 1098-1110.

Eddyono, F., Darusman, D., Sumarwan, U. and Sunarminto, T. (2021b), "Tourism competitiveness on the utilization zone of National Park in Indonesia", Jurnal Penelitian Kehutanan Wallacea, Vol. 10 No. 2, pp. 145-164. 
Fajnylber, F. (1988), International Competitiveness : Agreed Goal, Hard Task, Cepal Review, December.

Fennell, D.A. (1999), Ecotourism: An Introduction, Routledge.

Fennell, D. (2013), "Ecotourism, animals and ecocentrism: a re-examination of the billfish debate", Tourism Recreation Research, Vol. 38 No. 2, pp. 189-202.

Forrester, J.W. (1994), "System dynamics, systems thinking, and soft OR", System Dynamics Review, Vol. 10 Nos 2-3, pp. 245-256.

Forsyth, M. and Farran, S. (2013), Issue on Creativity, Innovation, Access to Knowledge and Development in Pacific Island Countries, ANU Research Publications.

Fuchs, M., Höpken, W. and Lexhagen, M. (2014), "Big data analytics for knowledge generation in tourism destinations-A case from Sweden", Journal of Destination Marketing and Management, Vol. 3 No. 4, pp. 198-209.

Gao-jun, N.P.F.L. and Xuan-tao, S.O.N.G. (2003), "Cluster analysis on Chinese urban competitiveness", China Industrial Economy, Vol. 3.

Geiger, M. and Goh, C. (2012), "Ethiopia economic Update 7", Ethiopia Economic Update 7. doi: 10. 1596/31503.

Gössling, S. and Hultman, J. (2006), "Ecotourism in Scandinavia: lessons in theory and practice", Ecotourism in Scandinavia: Lessons in Theory and Practice, Vol. 4, Cabi, pp. 1-211, doi: 10.1016/j.annals. 2007.03.007.

González, P. and Moral, P. (1995), "An analysis of the international tourism demand in Spain", International Journal of Forecasting, Vol. 11 No. 2, pp. 233-251, doi: 10.1016/0169-2070(94)00570-3.

Goodwin, H. (1996), "In pursuit of ecotourism", Biodiversity and Conservation, Vol. 5 No. 3, pp. 277-291.

Gooroochurn, N. and Sugiyarto, G. (2005), "Competitiveness indicators in the travel and tourism industry", Tourism Economics, Vol. 11 No. 1, pp. 25-43.

Gretzel, U., Sigala, M., Xiang, Z. and Koo, C. (2015), "Smart tourism: foundations and developments", Electronic Markets, Vol. 25 No. 3, pp. 179-188.

Gunadhi, H. and Boey, C.K. (1986), "Demand elasticities of tourism in Singapore", Tourism Management, Vol. 7 No. 4, pp. 239-253.

Heerschap, N., Ortega, S., Priem, A. and Offermans, M. (2014), "Innovation of tourism statistics through the use of new big data sources", 12th Global Forum on Tourism Statistics, Prague, CZ, p. 716.

Hiller, F.S. and Liberman, G.J. (1980), Introduction to Operations, 9th ed., Holden Day.

Hiwasaki, L. (2006), "Community-based tourism: a pathway to sustainability for Japan's protected areas", Society and Natural Resources, Vol. 19 No. 8, pp. 675-692.

Jackson, S. (2016), "Prediction, explanation and big (ger) data: a middle way to measuring and modelling the perceived success of a volunteer tourism sustainability campaign based on 'nudging'”, Current Issues in Tourism, Vol. 19 No. 7, pp. 643-658.

Jones, J.N., Cope, J. and Kintz, A. (2016), "Peering into the future of innovation management", ResearchTechnology Management, Vol. 59 No. 4, pp. 49-58.

Kiper, T. (2013), Role of Ecotourism in Sustainable Development, InTech. doi: 10.5772/55749.

Kitchin, R. (2013), "Big data and human geography: opportunities, challenges and risks", Dialogues in Human Geography, Vol. 3 No. 3, pp. 262-267.

Kitchin, R. (2014), "The real-time city? Big data and smart urbanism”, GeoJournal, Vol. 79 No. 1, pp. 1-14.

KLHK (2017), Buku Pariwisata Alam 54 Taman Nasional Jelajah Keindahan Panorama Dan Keunikan Fenomena Alam Indonesia, Direktorat Pemanfaatan Jasa Lingkungan Hutan Konservasi, Kementerian Lingkungan Hidup dan Kehutanan Republik Indonesia.

Leiper, N. (1979), "The framework of tourism: towards a definition of tourism, tourist, and the tourist industry", Annals of Tourism Research, Vol. 6 No. 4, pp. 390-407.

Lewis, G. (2008), "Innovation and productivity: using bright ideas to work smarter", New Zealand Treasury.

Lovelock, C. and Patterson, P. (2015), Services Marketing, Pearson Australia.

Manning, R.E. (2013), Parks and Carrying Capacity: Commons without Tragedy, Island Press.

PAGE $16 \mid$ JOURNAL OF TOURISM FUTURES $\mid$ VOL. $\mathbf{m}$ NO. $\mathbf{m}$ 
Marchese, M. (2009), "Issues paper", International Conference on SMEs, Entrepreneurship and Innovation, Villa Manin of Passariano (Udine), OECD LEED Programme.

Marimin (2005), Teknik Majemuk, Aplikasi Pengambilan Keputusan Kriteria, 2nd ed., Grasindo, Jakarta: Grasindo.

Martin, C.A. and Witt, S.F. (1988), "Substitute prices in models of tourism demand", Annals of Tourism Research, Vol. 15 No. 2, pp. 255-268, doi: 10.1016/0160-7383(88)90086-2.

Mieczkowski, Z. and Chadee, D. (1987), "Canadian tourism at the turning point", The Tourist Review, Vol. 42 No. 3, pp. 2-6.

Mowforth, M. and Munt, I. (2015), Tourism and Sustainability: Development, Globalisation and New Tourism in the Third World, Routledge.

Narendra, A.P. (2015), "Data besar, data analisis, dan pengembangan kompetensi pustakawan", Record and Library Journal, Vol. 1 No. 2, pp. 83-93.

OECD (1992), Technology and the Economy: The Key Relationships, Technology/Economy Programme.

Pansiri, J. (2014), "Tourist motives and destination competitiveness: a gap analysis perspective", International Journal of Hospitality and Tourism Administration, Vol. 15 No. 3, pp. 217-247, doi: 10.1080/ 15256480.2014 .925718$.

Papatheodorou, A. (1999), "The demand for international tourism in the Mediterranean region", Applied Economics, Vol. 31 No. 5, pp. 619-630, doi: 10.1080/000368499324066.

Patsouratis, V., Frangouli, Z. and Anastasopoulos, G. (2005), "Competition in tourism among the Mediterranean countries”, Applied Economics, Vol. 37 No. 16, pp. 1865-1870, doi: 10.1080/ 00036840500217226.

Petruzzelli, A.M., Rotolo, D. and Albino, V. (2012), "The impact of old technologies on innovation: the case of the US biotechnology industry", Technology Analysis and Strategic Management, Vol. 24 No. 5, pp. 453-466, doi: 10.1080/09537325.2012.674668.

Raguseo, E. (2018), "Big data technologies: an empirical investigation on their adoption, benefits and risks for companies", International Journal of Information Management, Vol. 38 No. 1, pp. 187-195.

Ritchie, J.R., Crouch, G.I. and Hudson, S. (2000), "Assessing the role of consumers in the measurement of destination competitiveness and sustainability", Tourism Analysis, Cognizant Communication Corporation, Vol. 5 Nos 2-3, pp. 69-76.

Roberts, J.T., Thanos, N.D. and Korovkin, T. (2005), "Latin eco action [trouble in paradise: globalization and environmental crises in Latin America]", Alternatives Journal, Vol. 31 No. 1, p. 36.

Sangpikul, A. (2008), "A critical review of ecotourism studies in Thailand”, Tourism Analysis, Vol. 13 No. 3, pp. 281-293.

Schwab, K. (2016), The Fourth Industrial Revolution, World Economic Forum.

Scuotto, V., Del Giudice, M., Bresciani, S. and Meissner, D. (2017), "Knowledge-driven preferences in informal inbound open innovation modes. An explorative view on small to medium enterprises", Journal of Knowledge Management.

Song, H., Witt, S.F. and Li, G. (2008), The Advanced Econometrics of Tourism Demand, Routledge.

Sterman, J. (2000), System Dynamics: Systems Thinking and Modeling for a Complex World, McGraw-Hill Education.

Sterman, J.D. (2002), "System dynamics modeling: Tools for learning in a complex world", IEEE Engineering Management Review, Vol. 30 No. 1, pp. 42-52, doi: 10.1109/EMR.2002.1022404.

Sukirno, S. (2004), Makroekonomi Teori Pengantar, PT Raja Grafindo Perkasa.

Sushil (1993), System Dynamics: A Practical Approach for Managerial Problems, Wiley Eastern.

Tasrif, M. (2006), Analisis Kebijakan Menggunakan Model System Dynamics, Program Magister Studi Pembangunan ITB.

Taylor, T. and Ortiz, R.A. (2009), "Impacts of climate change on domestic tourism in the UK: a panel data estimation”, Tourism Economics, Vol. 15 No. 4, pp. 803-812, doi: 10.5367/000000009789955161.

The International Ecotourism Society (2000), Ecotourism Statistical Fact Sheet, The International Ecotourism Society, Burlington, Vermont. 
The World Economic Forum (2018), "The travel \& tourism competitiveness".

Thompson, A. and Thompson, H. (2010), "Research note: the exchange rate, euro switch and tourism revenue in Greece", Tourism Economics, Vol. 16 No. 3, pp. 773-780, doi: 10.5367/000000010792278338.

Tussyadiah, I.P. (2014), "Toward a theoretical foundation for experience design in tourism", Journal of Travel Research, Vol. 53 No. 5, pp. 543-564.

UNWTO, E.T.C. (2015), The Decision-Making Process of Meetings, Congresses, Conventions and Incentives Organizers, Madrid.

UNWTO (2017), "Electronic resource”, Electronic Resource.

Van der Merwe, P. and Saayman, M. (2008), "Travel motivations of tourists visiting kruger national park", Koedoe, Vol. 50 No. 1, pp. 154-159, doi: 10.4102/koedoe.v50i1.140.

Vargo, S.L. and Akaka, M.A. (2009), "Service-dominant logic as a foundation for service science: clarifications", Service Science, Vol. 1 No. 1, pp. 32-41.

Wahab, S. (1977), Tourism Management, Tourism International, London Press.

WTO (2004), Indicators of Sustainable Development for Tourism Destinations, World Tourism Organization (WTO).

Wu, L., Yuan, L. and You, J. (2015), "Survey of large-scale data management systems for big data applications", Journal of Computer Science and Technology, Vol. 30 No. 1, pp. 163-183.

Yamada, N. (2011), "Why tour guiding is important for ecotourism: enhancing guiding quality with the ecotourism promotion policy in Japan", Asia Pacific Journal of Tourism Research, Vol. 16 No. 2, pp. 139-152.

Yamin, H.Y. and Shahidehpour, S.M. (2004), "Bidding strategies using price based unit commitment in a deregulated power market", Electric Power Components and Systems, Vol. 32 No. 3, pp. 229-245.

Yoeti, O. (2008), Ekonomi Pariwisata Introduksi, Informasi, Dan Implementasi, PT Kompas Media Nusantara.

Zed, M. (2004), Metode Penelitian Kepustakaan, Yayasan Obor Indonesia.

Zhang, Q., Yang, L.T., Chen, Z. and Li, P. (2018), "A survey on deep learning for big data", Information Fusion, Vol. 42, pp. 146-157.

\section{Corresponding author}

Fauziah Eddyono can be contacted at: fauziaheddyono@yahoo.co.id

For instructions on how to order reprints of this article, please visit our website: www.emeraldgrouppublishing.com/licensing/reprints.htm Or contact us for further details: permissions@emeraldinsight.com 